Article

\title{
Impact of Climate and Geology on Event Runoff Characteristics at the Regional Scale
}

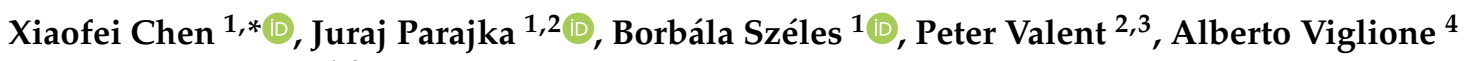 \\ and Günter Blöschl 1,2 \\ 1 Centre for Water Resource System, TU Wien, Karlsplatz 13, A-1040 Vienna, Austria; \\ parajka@hydro.tuwien.ac.at (J.P.); szeles@hydro.tuwien.ac.at (B.S.); bloeschl@hydro.tuwien.ac.at (G.B.) \\ 2 Institute of Hydraulic Engineering and Water Resources Management, TU Wien, Karlsplatz 13, \\ A-1040 Vienna, Austria; valent@hydro.tuwien.ac.at \\ 3 Department of Land and Water Resources Management, Faculty of Civil Engineering, Slovak University of \\ Technology in Bratislava, Radlinského 11, 81005 Bratislava, Slovakia \\ 4 Polytechnico di Torino, Department of Environment, Land and Infrastructure Engineering, \\ Corso Duca degli Abruzzi, 24, 10129 Torino, Italy; alberto.viglione@polito.it \\ * Correspondence: chen@waterresources.at
}

Received: 11 November 2020; Accepted: 7 December 2020; Published: 9 December 2020

\begin{abstract}
The dynamics of flood event characteristics, such as the runoff coefficient and the recession time constant, differ in time and space, due to differences in climate, geology, and runoff generation mechanisms. This study examines the variability of event runoff characteristics and relates them to climatic and hydro-geological characteristics available at the regional scale. The main focus is to examine the role of rainfall patterns (i.e., event precipitation volume, precipitation intensity, and antecedent precipitation) and runoff regime (i.e., initial flow before runoff event and event duration) characteristics on the seasonal dynamics of runoff response. The analysis is performed in four small Austrian catchments representing different hydro-geological settings obtained by field mapping. The results are based on an analysis of 982 runoff events identified from hourly measurements of streamflow and precipitation in the period 2002 to 2013. The results show that larger event runoff coefficients and flow peaks are estimated in catchments with high mean annual precipitation than in drier catchments. In contrast to some previous studies, the results show only poor relation between antecedent precipitation (as an index of catchment wetness) and event runoff response. The initial flow is found to be the main factor influencing the magnitude of runoff coefficient and event peaks in all analyzed catchments and geological settings. The recession time constant tends to be inversely related to the maximum event precipitation intensity, with an exception for one catchment (Wimitzbach), which is characterized by the largest proportion of deep interflow contribution to runoff. The analysis of the runoff response by different event types indicates that runoff coefficients and recession time constants are the largest for snowmelt runoff events.
\end{abstract}

Keywords: event runoff coefficient; event recession time constant; hydro-geological field mapping; regional scale

\section{Introduction}

Runoff event characteristics are an essential input for hydrologic design, as well as a diagnostic parameter in the hydrological analysis of runoff generation processes and catchment response to rainfall. The event runoff coefficient determines the proportion of rainfall that contributes to direct runoff during a flood event. It reflects the hydrological state of the catchment, but also the physiographic catchment characteristics, which are combining into runoff response. The runoff recession time constant describes 
the interaction between groundwater and river flow [1], and it indicates the time until streams return to their base flow conditions after a rainfall event [2]. Together with the magnitude of event peak flows, the understanding of runoff event characteristics is, thus, critical for many water-related tasks, including water supply, irrigation, water quality, erosion, and flood risk assessment [3,4].

Previous studies found that factors controlling event runoff characteristics were different in different spatial scales [5,6]. Plot and hillslope experiments demonstrated that runoff response at hillslope scale was controlled by the interactions between infiltration rates, change in soil water storage and drainage, and connectivity of the soil water [7-9]. Variability and differences in runoff response from plot to small catchment scale were controlled by the connectivity between the 'infiltrating' and 'runoff producing' areas [10,11]. At this scale, the event runoff coefficients tended to decrease with increasing catchment area, and the recession time constants and runoff peaks were controlled mainly by the land use $[3,11,12]$. At the catchment scale, the factors controlling runoff formation are less understood, mainly due to the variability in the connectivity of flow paths and larger spatial variability of catchment physiographic characteristics [11,13-15]. At the regional scale, the main controlling factors were attributed to mean annual precipitation and the runoff regime [1], physiographic catchment characteristics [16], and antecedent soil moisture [17,18].

The role of the subsurface characteristics on runoff response is still not well understood. Some studies considered the soil-bedrock interface as an impermeable boundary and hypothesized that subsurface storm flow occurred only in the soil layer [19]. On the contrary, some other studies demonstrated that flow through bedrock might play an essential role in rainfall-runoff response [20,21], and that the soil-bedrock interface could control the magnitude and timing of rainfall-runoff response or recession time constants during low flow conditions [22-25]. At the catchment scale, geology and groundwater flow paths control the transit time distribution of water within catchments [26]. In a comparative hydrology study, Gaál et al. (2012) showed that geology was, together with climate, an even stronger control in determining event runoff characteristics than the catchment area [27]. Although geology was often cited as an important factor driving hydrological response at the catchment scale $[4,21,28,29]$, the challenge in attributing subsurface and geological conditions to runoff response is a lack of detailed geological field observations.

The main objective of this study is to examine the variability of selected event runoff characteristics and relates them to climatic and geological characteristics available at the regional scale. We focus on the seasonal differences of event runoff coefficients, recession time constants, and event peaks in four small Austrian catchments with available detailed geological characteristics estimated by field mapping according to Viglione et al. [4]. The aim is to examine the role of rainfall patterns (i.e., event precipitation volume, precipitation intensity, and antecedent precipitation) and runoff regime (i.e., initial flow before runoff event and event duration) characteristics on the seasonal dynamics of runoff response in different geological settings.

\section{Data}

\subsection{Study Catchments}

This study is conducted in four Austrian catchments: Wimitzbach, Perschling, Gail, and Dornbirnerach. These catchments represent four hot spot regions identified by Gaál et al. (2012), which are unique in terms of climate, geology, soils, and landform types [27]. These four catchments represent the high alpine region (Gail), alpine/midland setting (Dornbirnerach and Wimitzbach), and lowland areas (Perschling). The geological classes and location of these catchments in Austria are presented in Figure 1. The overview of the main climate and physiographic characteristics of the catchments is listed in Table 1. 


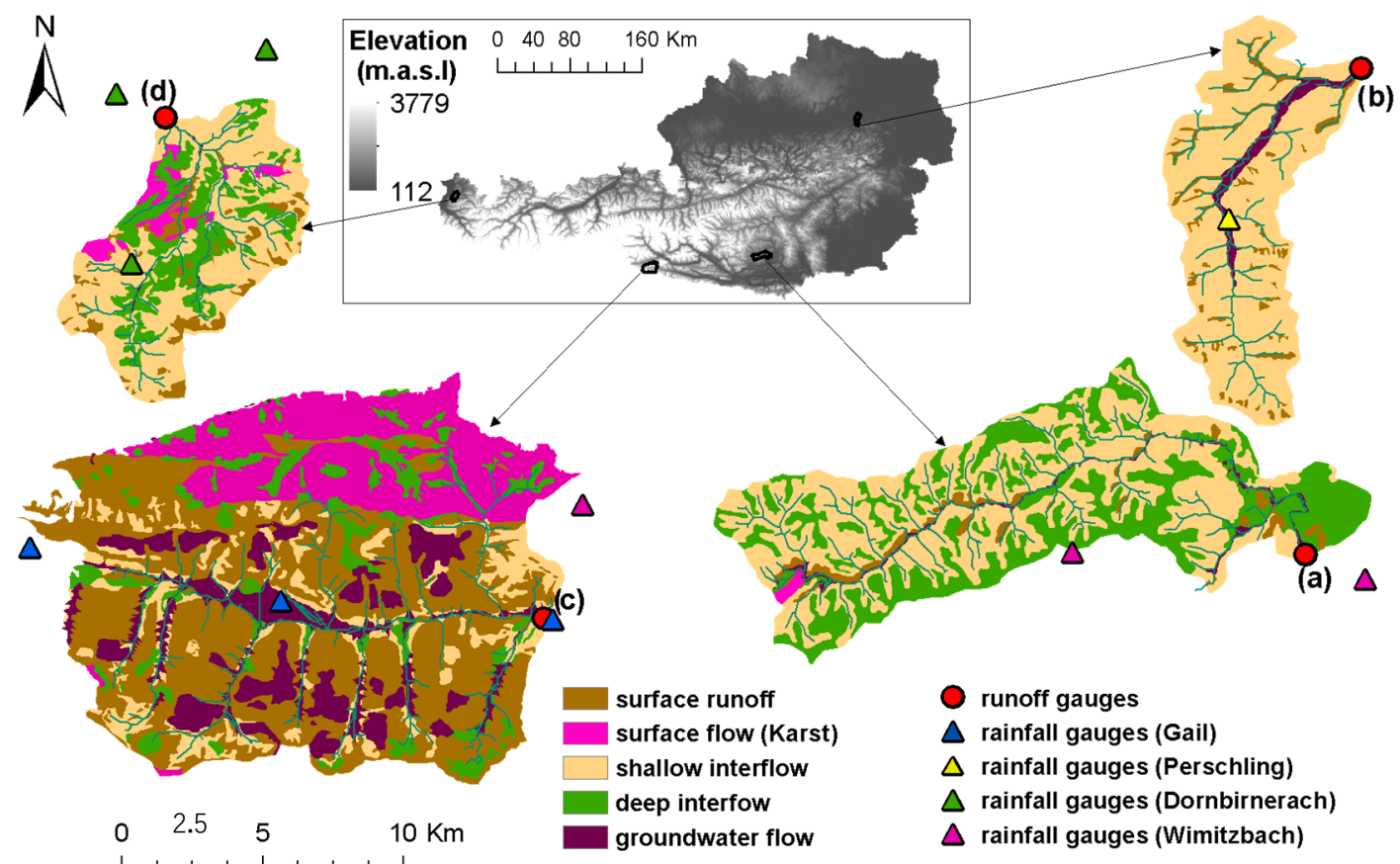

Figure 1. Locations and geological classes of the four catchments presented in this study: (a) Wimitzbach, (b) Perschling, (c) Gail, and (d) Dornbirnerach [4]. Streamflow lines are presented as green lines in each catchment. The runoff gauges are shown with circle points, while the rainfall gauges with triangle points.

Table 1. Catchment overview. Temporal means of catchment attributes are lumped basin averages from 2002-2013. The hydro-geologic information describes the proportion (area percentage) of the geological classes.

\begin{tabular}{ccccc}
\hline Attribute & Wimitzbach & Perschling & Gail & Dornbirnerach \\
\hline Hotspot region [27] & Gurktal (Gurk) & Flysch (Flysch) & Gail (Gail) & Bregenzerwald (BreWa) \\
ID number & 213,256 & 209,486 & 212,613 & 200,204 \\
Area $\left(\mathrm{km}^{2}\right)$ & 106.5 & 55.3 & 146.1 & 51.1 \\
Mean slope (\%) & 39.4 & 14.3 & 53.4 & 45.0 \\
Min-max elevation (m) & $529-1309$ & $230-640$ & $1094-2622$ & $485-1804$ \\
Mean elevation (m) & 900 & 379 & 1793 & 1118 \\
Maximum flow length (km) & 30.8 & 18.6 & 23.3 & 13.9 \\
Mean annual runoff (mm/year) & 273 & 301 & 869 & 1793 \\
Mean annual prec. (mm/year) & 744 & 876 & 1081 & 1982 \\
Mean annual daily air temp. ( $\left.{ }^{\circ} \mathrm{C}\right)$ & 7.8 & 10.0 & 3.5 & 6.8 \\
Mean of max. prec. (mm/h) & 14.9 & 19.7 & 13.7 & 24.0 \\
Mean of max. prec. (mm/6 h) & 31.7 & 44.4 & 35.0 & 50.0 \\
Mean of max. prec. (mm/24 h) & 52.1 & 78.2 & 62.6 & 105.6 \\
Mean annual runoff coefficient (-) & 0.37 & 0.34 & 0.80 & 0.90 \\
Proportion of surface runoff area (\%) & 4.0 & 0 & 7.7 & 9.5 \\
Proportion of area with Karst $(\%)$ & 0.5 & 0 & 51.0 & 6.0 \\
Proportion of area with shallow interflow (\%) & 55.4 & 93.5 & 14.0 & 6.0 \\
Proportion of area with deep interflow (\%) & 37.6 & 0 & 6.3 & 24.0 \\
Proportion of area with groundwater flow (\%) & 2.5 & 6.5 & 20.0 & 0.5 \\
\hline
\end{tabular}

The Dornbirnerach is an alpine catchment $\left(51 \mathrm{~km}^{2}\right)$ located in the western part of Austria. The elevation ranges from $485 \mathrm{~m}$ a.s.l. to $1804 \mathrm{~m}$ a.s.l., and it is characterized by very steep slopes (mean slope is $45 \%$ ). The catchment is mainly forested, grassland and pastures are sparsely located in the higher elevations. The catchment is characterized by shallow soils and a large amount of annual precipitation (over $1900 \mathrm{~mm} / \mathrm{year}$ ), which results in highly saturated soils, and hence, a high mean annual runoff coefficient.

The Gail is the highest, steepest and largest catchment in this study, with a total area of $146 \mathrm{~km}^{2}$ and a maximum flow length of $23.3 \mathrm{~km}$. It is located in the Eastern Tyrol, and its elevations range from 
1094 to 2622 m.a.s.l. The land cover is dominated by forest and grassland on hillslopes and arable land and pastures in the valley bottom.

The Wimitzbach is a midland catchment in Carinthia. It is mainly covered by forest, with small parts of arable land in the middle and lower parts of the catchment. The mean annual precipitation of Wimitzbach is the lowest (less than $750 \mathrm{~mm} /$ year) among the study catchments.

The lowlands are represented by the Perschling catchment, which is located in Lower Austria. The elevation ranges from $230 \mathrm{~m}$ to $640 \mathrm{~m}$ a.s.l. The catchment is dominated by forest in the southern part and agricultural areas in the northern part and has the lowest annual runoff coefficient.

For the four study sites, the description of the dominant runoff processes based on hydro-geologic information was prepared by a geologist $[30,31]$. The report includes information about different hydro-geologic response units. In each catchment, areas dominated by different flow paths, i.e., interflow, deep groundwater flow, or surface runoff processes, were mapped. More information about the implementation of the geological mapping method are given by Rogger et al. and Viglione et al. $[4,29,32]$. The geologic conditions and proportion of different units describing the hydro-geologic runoff processes in the four study sites are presented in Figure 1 and listed in Table 1. The Dornbirnerach is part of the Helvetic zone, which is dominated by limestone, sandstone, and marl with a small amount of flysch in the northern area. The largest part of the catchment $(60 \%)$ is characterized by shallow interflow flow paths. The scree areas in the lower parts of the hillslopes have rather large depth and are dominated by deeper interflow processes, which may buffer some of the fast surface runoff generated in the upper parts [4]. The Gail is part of the Karnic Alps, the Gail crystalline, and the Lienzer dolomites. More than $51 \%$ of runoff process in the Gail catchment is characterized as near-surface and surface runoff from the karst area. The central valley is east-west orientated with rather steep valleys discharging into the Gail from north and shallower valleys from the south. Runoff retention and deep groundwater flow occur on the large alluvial cone in the valley bottom. During very wet conditions, however, the valley bottom can get saturated so that tributaries can bypass it [4]. The Wimitzbach is characterized by mica schist, phyllites, amphibolites, and marble. The hillslopes are plane in the upper parts and steeper in the lower parts. The Wimitzbach was not glaciated during the last ice age, so the upper parts of the hillslopes are strongly weathered and characterized by deep interflow flow paths (37.6\%). The lower parts of the hillslopes are steeper and are characterized by faster storage, due to shallow interflow or surface runoff flow paths. The Perschling catchment is located in the flysch/molasse zone of Austria. The whole catchment is characterized by interflow processes in the weathering zone that has a depth from 2 to $5 \mathrm{~m}$. Sandy gravel in the valley bottom influences the groundwater flow paths. On the upper parts of the hillslopes, water infiltrates into the shallow subsurface, while at the slope toes, some saturation and surface runoff may occur [4].

\subsection{Meteorological and Hydrological Data}

The event runoff characteristics are estimated from hourly runoff and rainfall data observed in the period 2002-2013. The measurements of runoff are carried out at 15-min temporal resolution and aggregated to hourly values. The mean catchment hourly rainfall is interpolated from hourly observations by using the Thiessen polygon method. The location of the rainfall gauges is shown in Figure 1. The aggregated annual rainfall and runoff values are presented in Figure 2. The evaluation of mean annual runoff and precipitation indicates that the largest annual precipitation, runoff, and their interannual variability is observed in Dornbirnerach, followed by the Gail catchment. The annual precipitation in Wimitzbach and Perschling catchment is slightly lower than in Gail. The mean values of precipitation in the period 2002-2013 are in all catchments about 10\% larger than observed in the period 1961-2017. Still, the mean annual runoff is significantly smaller, indicating the role of vegetation and evapotranspiration processes on the water balance. 


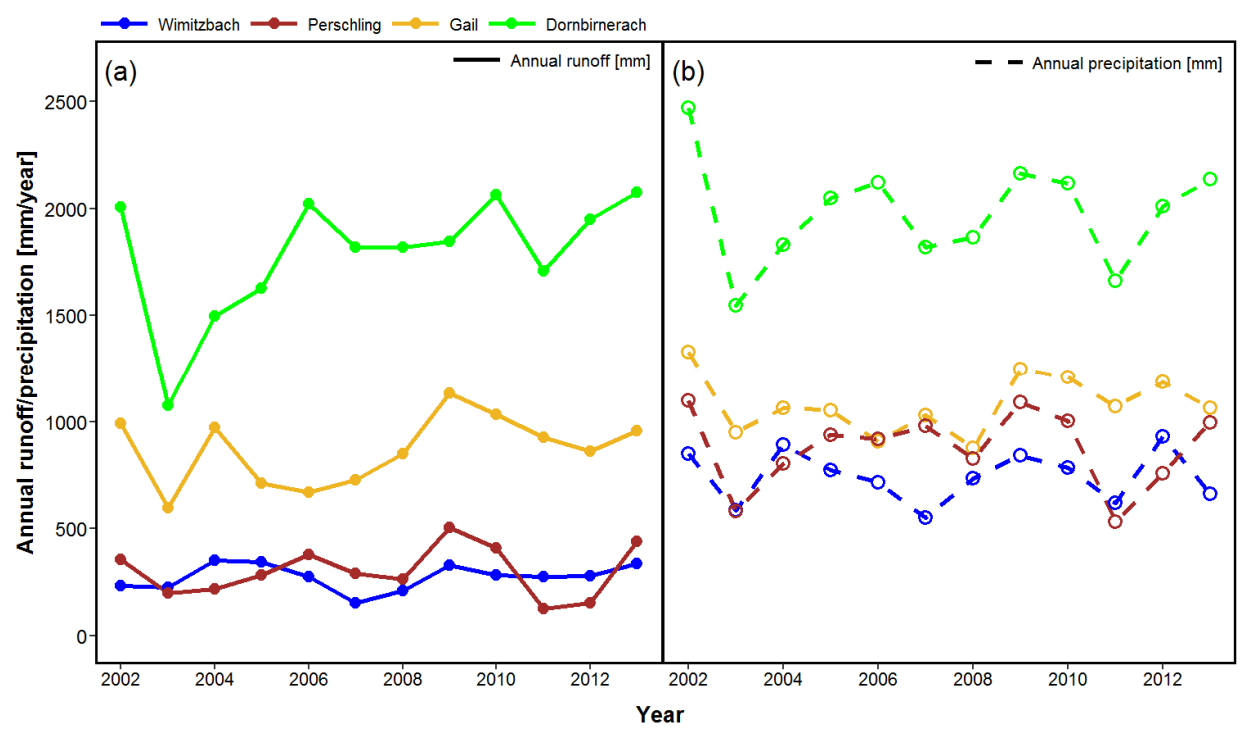

Figure 2. Inter-annual dynamics of mean annual precipitation (a) and runoff (b) in four Austrian catchments in the period 2002-2013.

\section{Methods}

\subsection{Estimation of Event Runoff Characteristics}

The rainfall-runoff events are separated using the methodology presented by Merz et al. [1]. The approach consists of the following steps:

1. Determination of direct runoff and baseflow;

2. Identification of the start and end of the runoff events;

3. Calculation of the selected event runoff characteristics, i.e., peak discharge, runoff coefficient, and recession time constant.

Baseflow is estimated by an automatic digital filter proposed by Chapman and Maxwell [33]. The details of the applied digital filter are described in detail in Merz et al. [1]. Runoff event peaks are identified, if the ratio of direct runoff and baseflow at time $t$ is larger than a threshold value of parameter qdrat and there was no larger flow in the previous and following imax (h) time steps. The parameters qdrat and imax are chosen in this study to be 2 and $12 \mathrm{~h}$, respectively, based on sensitivity analyses [1,5]. Storage parameter $\mathrm{k}_{2}(\mathrm{~h})$ used to determine runoff recession is chosen to be $5 \mathrm{~h}$ for Dornbirnerach and $7 \mathrm{~h}$ for Wimitzbach, Perschling, and Gail. These values are determined by visual inspection of the hourly runoff data time series for each catchment.

The start of an event is determined by searching backward from a peak to find the time when the direct runoff is less than $1 \%$ of the direct runoff at peak time. The number of time steps in the backward search (size of the time window) depends on the characteristic time scale of an event [1]. If no such point in the predefined time window is found, a higher limit for minimum direct runoff is allowed (stepwise increased from $1 \%$ to $40 \%$ ). The end of an event is found in an analog way by searching forwards [5].

For each runoff event, we estimate three characteristics: The event runoff coefficient (Rc), the event recession time constant (Tc), and the event peak flow (Qp). The runoff coefficient Rc and recession time constant Tc are determined by an automatic calibration using the shuffled complex evolution optimization scheme [34]. The linear reservoir model is fitted to the direct flow (the difference between runoff observation and base flow) by minimizing the root mean square difference between observed and simulated runoff. In the next step, final hydrographs are visually checked, and in some cases, Tc is manually adjusted and fixed to match the form one would separate manually. Subsequently, Rc is 
again automatically optimized until the simulated hydrograph fits the observed one. More details on the method are given by Merz et al. [1].

The impact of solid precipitation and snowmelt on the magnitude of event runoff characteristics is accounted for by using a daily snowmelt model. The model used in this study is a semi-distributed conceptual model (TUWmodel) [35], which is calibrated to daily observed discharge time series [36]. The snow simulations of the model are disaggregated to hourly values following the approach of Merz et al. [1]. We assume a constant ratio of liquid to solid precipitation for each day from which liquid hourly precipitation is estimated. For the temporal pattern of snowmelt during a day, a truncated cosine statistical distribution is applied, where snowmelt starts at 09:00, the maximum occurs at 15:00 and snowmelt ceases at 21:00 [5]. Finally, hourly precipitation in different catchments is calculated by removing snow and adding melt to rainfall in each time step.

\subsection{Potential Impact Variables of Flood Response}

For each identified flood event, seven potential variables are estimated, including event volume, event duration, initial flow, event precipitation, antecedent precipitation, maximum precipitation intensity, and melt percentage. Event volume is the sum of runoff observations during the identified event period in $\mathrm{mm}$. Event duration is the length of the identified event period in hours. For understanding catchment water storage before the event, initial flow is calculated as the value of runoff at the identified start time in the unit of $\mathrm{mm} / \mathrm{h}$. Event precipitation is the sum of precipitation during the identified event period in $\mathrm{mm}$. Antecedent precipitation is calculated by summing precipitation 30 days before the event in the units of $\mathrm{mm}$, which could reflect soil moisture condition before the event in a way. Maximum precipitation intensity is the peak precipitation during one event. Melt percentage is the volume ratio between melt and precipitation during the event period. In order to compare distributions of the above variables on event runoff and precipitation between different catchments, Gaussian kernel density, and empirical cumulative density function are estimated in Section 4.

\section{Results}

Table 2 summarizes the seasonal frequency of the identified runoff characteristics in four selected catchments in the period 2002-2013 (Table S1). Based on melt percentage, events are divided into two categories: Rainfall and melt events. In the following discussions, flood events are included in melt events when their melt percentage is larger than 0.1. The largest number of events is identified in Dornbirnerach, which is a catchment with the largest mean annual precipitation. More than 300 events are driven by rainfall, and 55 events are classified as snowmelt events. A much smaller number of events, only 123, is identified in the midland catchment of Wimitzbach, which has the smallest mean annual precipitation among the studied catchments. Seasonally, the largest number of events is observed during the summer months (June to August) in all catchments.

The statistical evaluation of selected event runoff characteristics is summarized in Table 3. The comparison indicates a distinct difference between the catchments. While the largest Rc and Qp are observed in Dornbirnerach (mean $R c=0.43$ and mean $Q p=1.6 \mathrm{~mm} / \mathrm{h}$ ), the smallest Rc and Qp are identified in Wimitzbach (mean Rc $=0.05$, mean $Q p=0.07 \mathrm{~mm} / \mathrm{h}$ ). The Dornbirnerach is the catchment with the wettest climate, as well as with the largest, i.e., $9.5 \%$ of the catchment that contributes to surface runoff. $7.7 \%$ of the catchment area of Gail contributes to surface runoff, and $20 \%$ of the catchment area contributes to groundwater flow. The mean Rc is 0.16 in Gail, but it has almost two times larger mean Tc compared to Dornbirnerach ( $12.5 \mathrm{~h}$ in Gail compared to $6.4 \mathrm{~h}$ in Dornbirnerach). The largest mean Tc $(18.1 \mathrm{~h})$ is found in Wimitzbach, which has the largest proportion of area with deep interflow. The Perschling has more than $90 \%$ area contributing to shallow interflow processes, which is reflected in the second smallest (fastest) mean Tc $(10 \mathrm{~h})$. This is an interesting finding because the catchment is situated in lowland, and the mean annual precipitation is the second lowest $(876 \mathrm{~mm})$. 
Table 2. The seasonal frequency of identified runoff events in Wimitzbach, Perschling, Gail, and Dornbirnerach catchments in the period 2002-2013.

\begin{tabular}{|c|c|c|c|c|c|c|}
\hline Catchments & $\begin{array}{l}\text { Flood Event } \\
\text { Types }\end{array}$ & $\begin{array}{c}\text { Spring } \\
\text { (March-May) }\end{array}$ & $\begin{array}{c}\text { Summer } \\
\text { (June-August) }\end{array}$ & $\begin{array}{c}\text { Autumn } \\
\text { (September-November) }\end{array}$ & $\begin{array}{c}\text { Winter } \\
\text { (December-February) }\end{array}$ & Total \\
\hline \multirow{3}{*}{ Wimitzbach } & Rainfall events & 23 & 69 & 26 & 2 & 120 \\
\hline & Melt events & 1 & 0 & 0 & 2 & 3 \\
\hline & Sum & 24 & 69 & 26 & 4 & 123 \\
\hline \multirow{3}{*}{ Perschling } & Rainfall events & 48 & 120 & 46 & 4 & 218 \\
\hline & Melt events & 7 & 0 & 5 & 20 & 32 \\
\hline & Sum & 55 & 120 & 51 & 24 & 250 \\
\hline \multirow{3}{*}{ Gail } & Rainfall events & 12 & 128 & 32 & 3 & 175 \\
\hline & Melt events & 10 & 2 & 4 & 0 & 16 \\
\hline & Sum & 22 & 130 & 36 & 3 & 191 \\
\hline \multirow{3}{*}{ Dornbirnerach } & Rainfall events & 63 & 183 & 93 & 24 & 363 \\
\hline & Melt events & 22 & 0 & 5 & 28 & 55 \\
\hline & Sum & 85 & 183 & 98 & 52 & 418 \\
\hline
\end{tabular}

Table 3. Summary of event runoff characteristics in Wimitzbach, Perschling, Gail, and Dornbirnerach catchments in the period 2002-2013.

\begin{tabular}{cccccc}
\hline \multicolumn{2}{c}{ Features of Event } & Wimitzbach & Perschling & Gail & Dornbirnerach \\
\hline & 5th percentile & 0.02 & 0.01 & 0.04 & 0.10 \\
Runoff coefficient & 95th percentile & 0.12 & 0.31 & 0.40 & 1.00 \\
(Rc) (-) & Mean & 0.05 & 0.09 & 0.16 & 0.43 \\
& Median & 0.05 & 0.05 & 0.11 & 0.37 \\
\hline & 5th percentile & 4.0 & 2.0 & 3.0 & 2.0 \\
Recession time & 95th percentile & 39.5 & 30.0 & 35.0 & 15.0 \\
constant (Tc) (h) & Mean & 18.1 & 10.3 & 12.5 & 6.4 \\
& Median & 15.0 & 7.1 & 9.0 & 5.0 \\
\hline & 5th percentile & 0.03 & 0.02 & 0.09 & 0.13 \\
Peak flow (Qp) & 95th percentile & 0.16 & 0.97 & 0.72 & 5.80 \\
$(\mathbf{m m} / \mathbf{h})$ & Mean & 0.07 & 0.23 & 0.25 & 1.57 \\
& Median & 0.06 & 0.07 & 0.18 & 0.89 \\
\hline
\end{tabular}

The seasonal distribution of event runoff coefficient $(\mathrm{Rc})$, recession time constant $(\mathrm{Tc})$, and event peak (Qp) for the four study catchments is presented in Figure 3. The variability in Rc indicates a clear seasonal pattern with larger Rc in winter and spring and smaller Rc in the summer. The seasonal variability of Rc is the highest in Dornbirnerach and the smallest in Wimitzbach catchment. Interestingly, the seasonal variability of Tc is the smallest in Dornbirnerach. More pronounced seasonal patterns of Tc are observed in Perschling and Gail catchments. The Gail catchment with $51 \%$ area generated runoff in Karst has the highest median Tc (40 h) in January/February and the lowest (6 h) in July/August. Such difference is likely connected to the seasonal catchment storage variation as discussed by Chen et al. and Patnaik et al. [5,37]. The largest event peaks are observed in all catchments in the summer months, and the smallest peaks tend to occur in winter. The seasonal variability of $\mathrm{Qp}$ is the largest in Dorbirnerach (it ranges from 0.7 to $1.0 \mathrm{~mm} / \mathrm{h}$ ), where the most extreme events with Qp larger than $2 \mathrm{~mm} / \mathrm{h}$, usually occur from May to August.

To understand the factors controlling runoff response in the study catchments, Figures 4 and 5 summarize the differences in the distributions of event flow and precipitation characteristics. Figure 4 demonstrates that the runoff coefficients and recession time constants are linked to the event flow volume. While the smallest event flow volumes are observed in Wimitzbach, the largest volumes are observed in the Dornbirnerach catchment. The small runoff coefficients in Wimitzbach are connected to small event flow volumes and larger event duration, and vice-versa. In contrast, the recession time constants tend to be the smallest in Dornbirnerach, which is characterized by events with large flow volumes, large runoff coefficients and the shortest event duration. Interestingly, the initial flow at the start of runoff events is noticeably larger in Dornbirnerach and Gail (median of initial flow larger 
than $0.08 \mathrm{~mm} / \mathrm{h}$ ) than in Perschling and Wimitzbach (median of initial flow less than $0.03 \mathrm{~mm} / \mathrm{h}$ ). The larger initial flow in Dornbirnerach and Gail is likely caused by seasonality of the runoff regime, i.e., larger flow in spring, due to snowmelt.

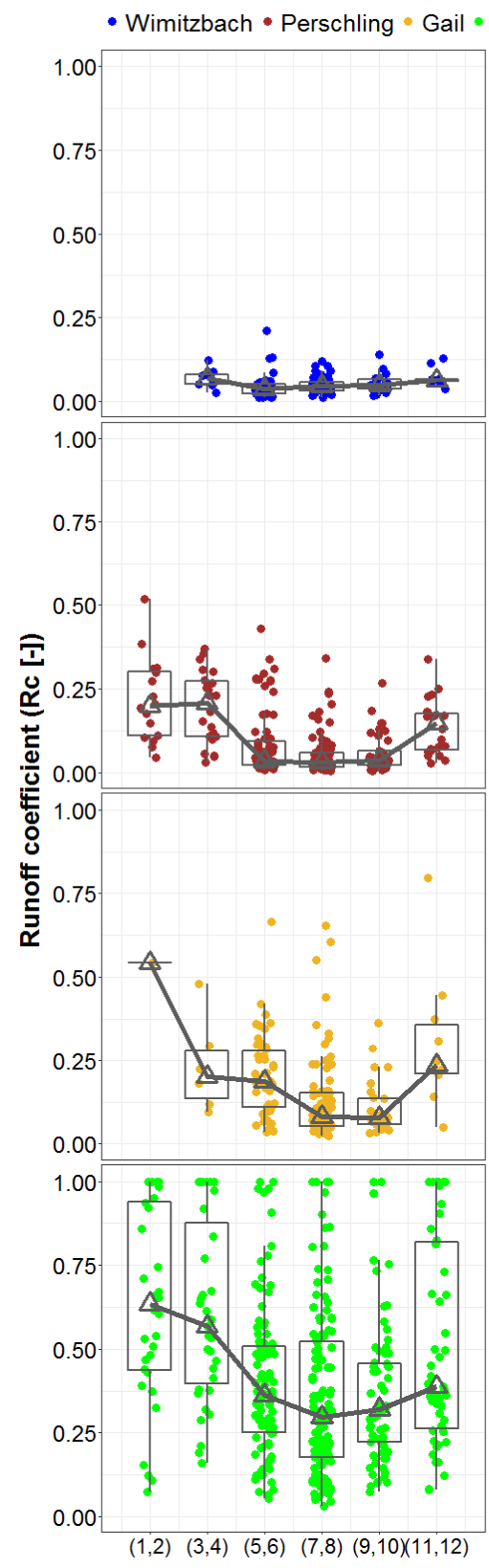

(a) Month

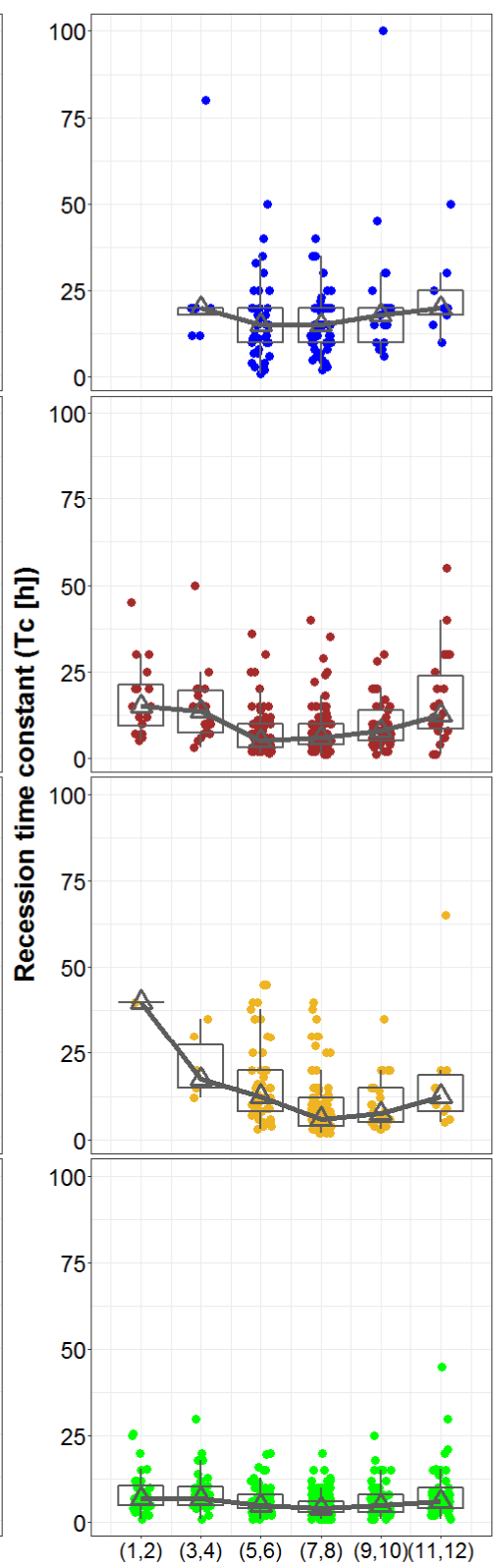

(b) Month

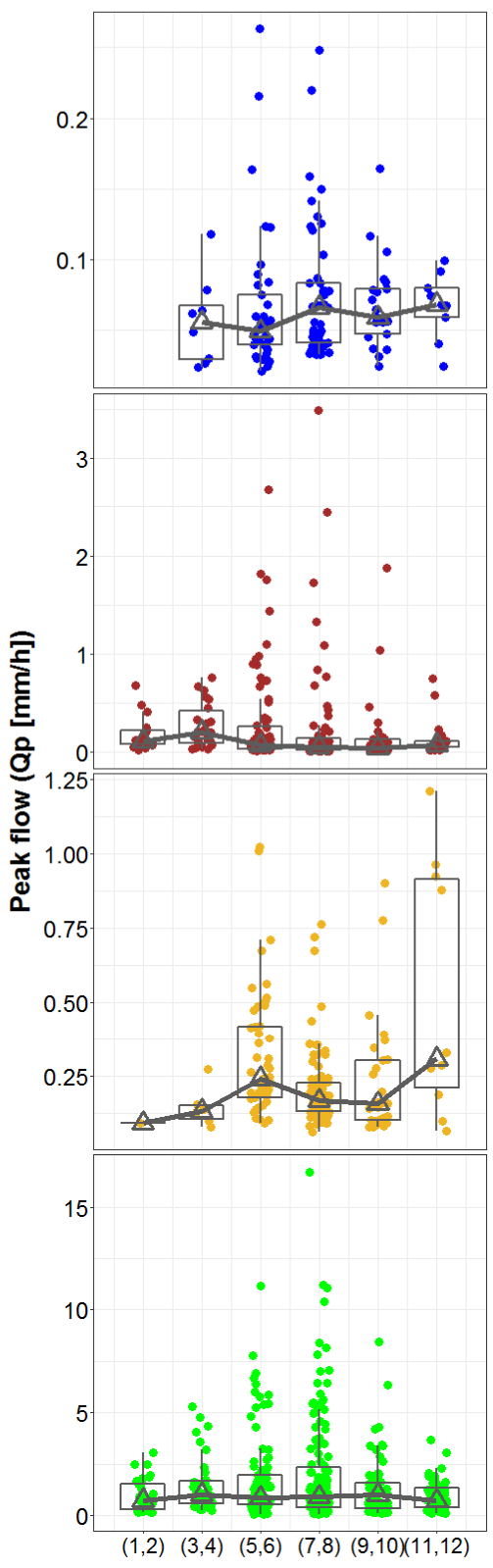

(c) Month

Figure 3. Seasonal dynamics of event runoff characteristics: The runoff coefficient (a), recession time constant (b), and peak flow (c) in the four study catchments.

Precipitation characteristics of the analyzed runoff events are evaluated in Figure 5. The statistical evaluation of the distributions of selected event characteristics shows that event precipitation volume and maximum intensities do not differ much between the four analyzed catchments. The medians of event precipitation volume of four catchments vary between 19 and $28 \mathrm{~mm}$, and for Dornbirnerach, the median is someawhat the largest of $28 \mathrm{~mm}$. The event precipitation volume follows the seasonality of precipitation, and it is larger in May and June and lowers in the winter months. An exception is Gail, where the largest precipitation events are observed in November. The maximum precipitation intensity during runoff events is similar in all catchments, while the median varies between 4.9 and 
$5.8 \mathrm{~mm} / \mathrm{h}$. The precipitation intensities are larger in the summer months, and the largest intensities (exceeding $10 \mathrm{~mm} / \mathrm{h}$ ) are observed in Dornbirnerach in July and August. The most noticeable difference is observed for the antecedent 30-days precipitation. This characteristic is used as an indicator of catchment wetness before the runoff events. The analysis indicates that Dornbirnerach is significantly wetter than the other catchments, and the median of antecedent precipitation is about $189 \mathrm{~mm}$, which is more than $100 \mathrm{~mm}$ larger than in Perschling or Wimitzbach. The antecedent precipitation is the largest in the summer months and follows the seasonality of the precipitation regime in Austria.

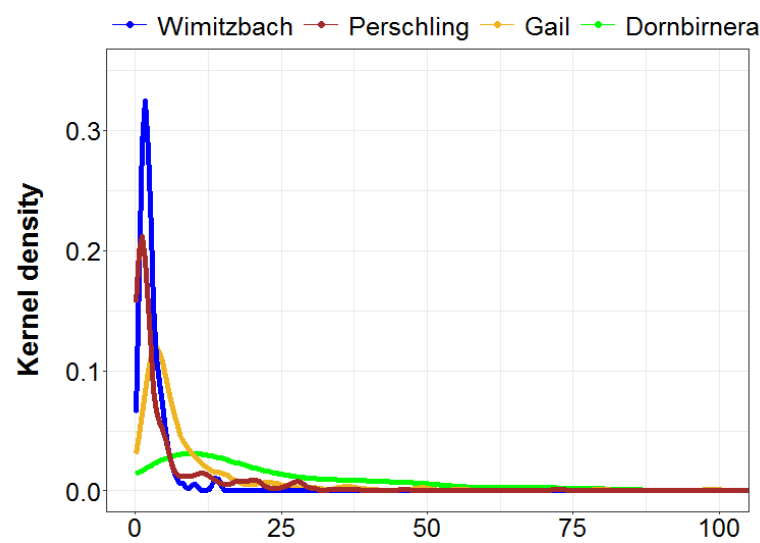

(a) Event volume $(\mathrm{mm})$

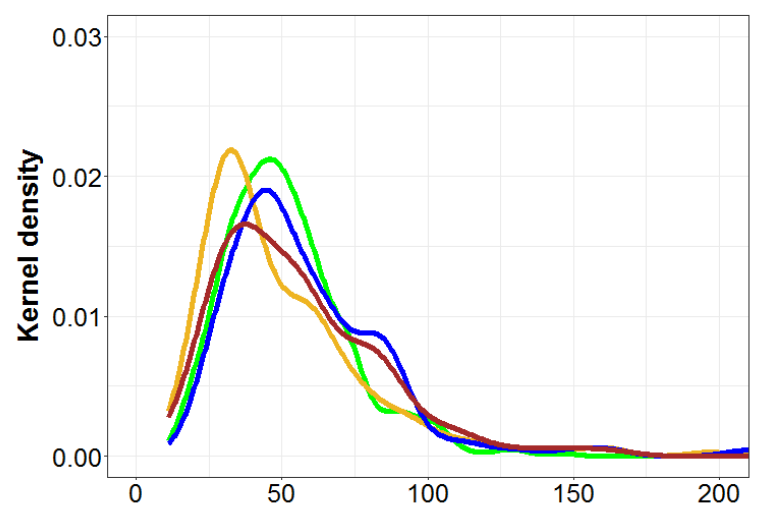

(c) Event duration (h)

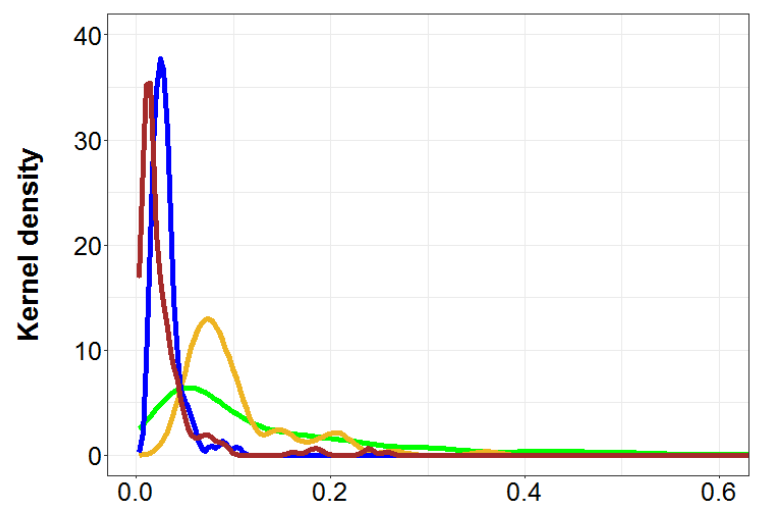

(e) Initial flow $(\mathrm{mm} / \mathrm{h})$

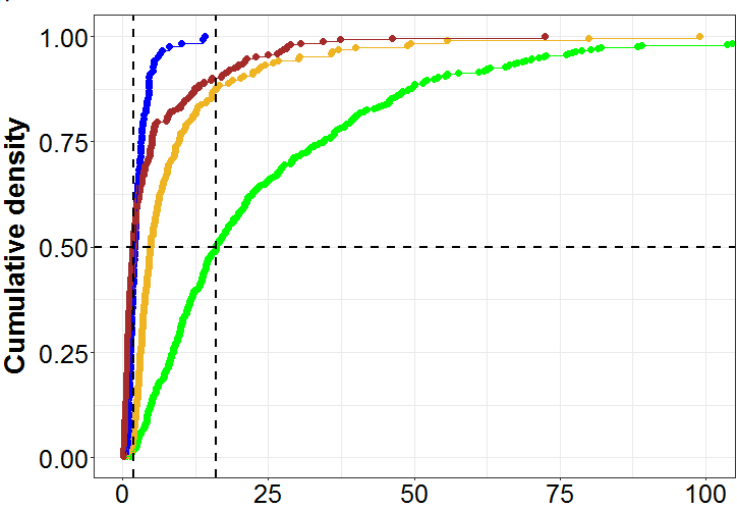

(b) Event volume (mm)

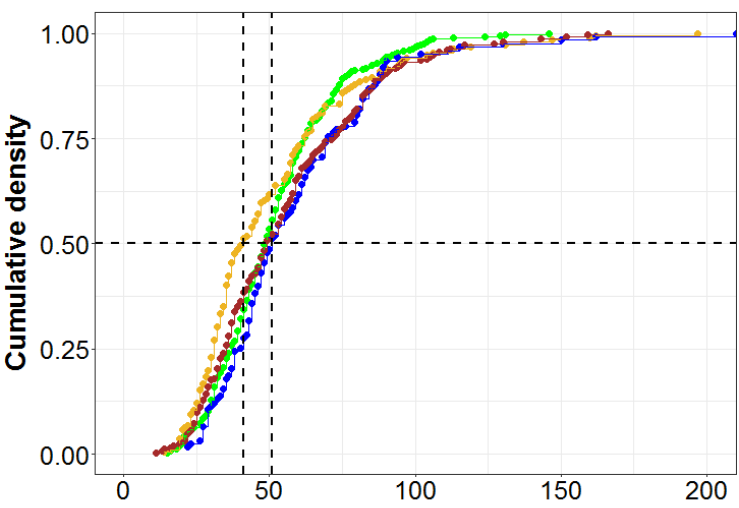

(d) Event duration (h)

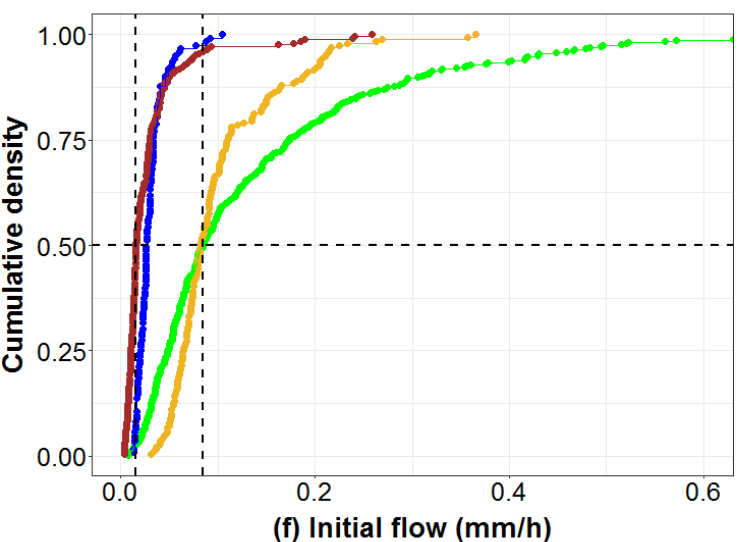

(f) Initial flow $(\mathrm{mm} / \mathrm{h})$

Figure 4. Kernel density (a,c,e) and cumulative density $(\mathbf{b}, \mathbf{d}, \mathbf{f})$ functions of event volume, duration, and initial flow (prior to the runoff event) in four selected catchments: Wimitzbach, Perschling, Gail, and Dornbirnerach. 


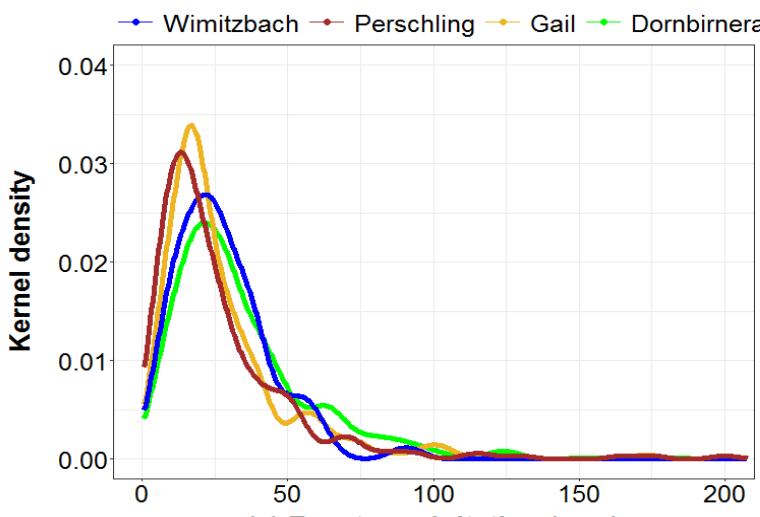

(a) Event precipitation $(\mathrm{mm})$

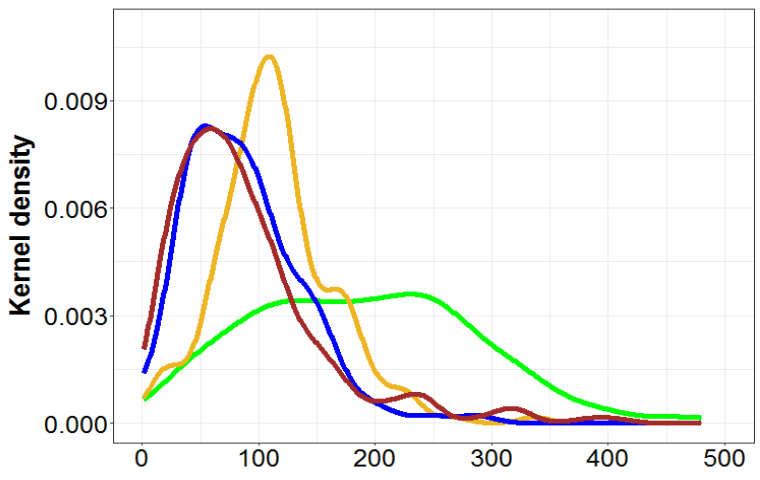

(c) Antecedent precipitation ( $\mathrm{mm}$ )

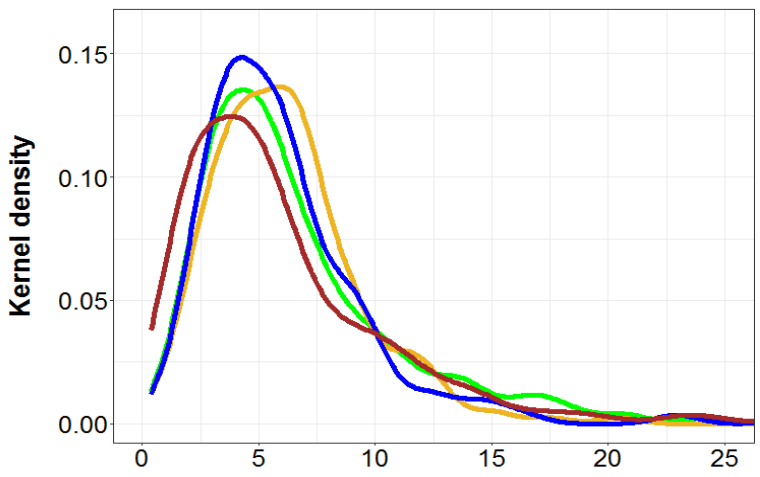

(e) Maximum precipitation intensity $(\mathrm{mm} / \mathrm{h})$

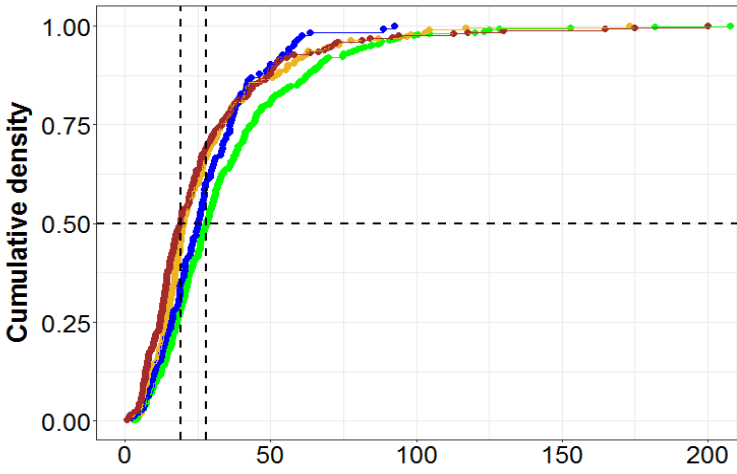

(b) Event precipitation ( $\mathrm{mm}$ )

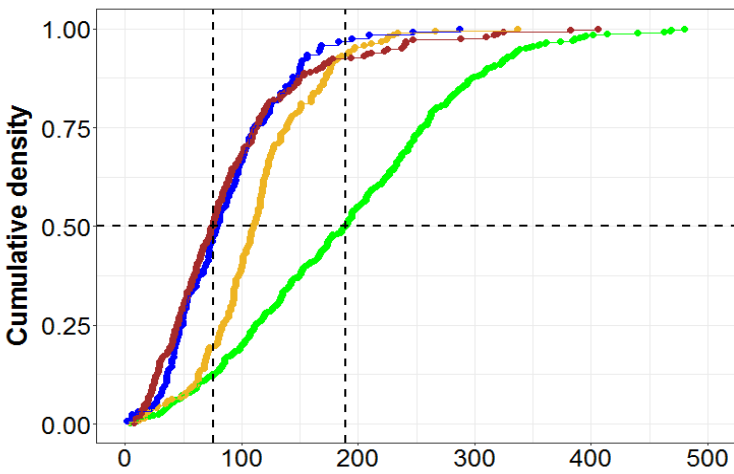

(d) Antecedent precipitation $(\mathrm{mm})$

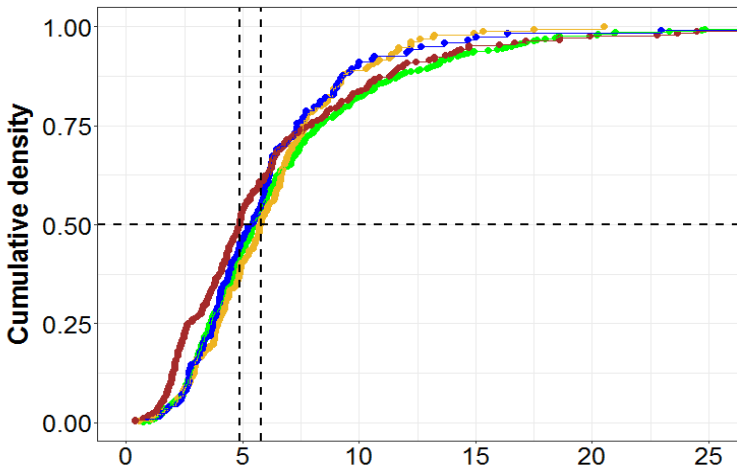

(f) Maximum precipitation intensity $(\mathrm{mm} / \mathrm{h})$

Figure 5. Kernel density $(\mathbf{a}, \mathbf{c}, \mathbf{e})$ and cumulative density $(\mathbf{b}, \mathbf{d}, \mathbf{f})$ functions of total precipitation volume during runoff event, maximum precipitation intensity, and 30-days antecedent precipitation volume (prior to the runoff event) in four selected catchments: Wimitzbach, Perschling, Gail, and Dornbirnerach.

The comparison of event precipitation volume (Figure 5) indicates that the majority (more than $75 \%$ ) of event precipitation volume is less than $50 \mathrm{~mm}$ in all catchments. To explore the differences in runoff response for similar precipitation events in all catchments (i.e., events precipitation less than $50 \mathrm{~mm}$ ), Figures $6-8$ show the change of runoff characteristics with changing antecedent precipitation, maximum precipitation intensity, initial flow, and event duration. The results in Figure 6 indicate that the antecedent precipitation is a poor indicator of the runoff coefficient. An increase of antecedent precipitation is not related to a significant rise in Rc. Interestingly, maximum precipitation is inversely associated with runoff coefficients. The Rc tends to be larger for events with smaller maximum precipitation intensity and vice versa. The most explanatory characteristic is the initial flow before the runoff event. The larger the initial flow is, the larger the runoff coefficient is observed in all catchments. In Karstic (Gail) and Flysch (Perschling) catchments, the Rc tends to increase with the increasing duration of runoff events. 

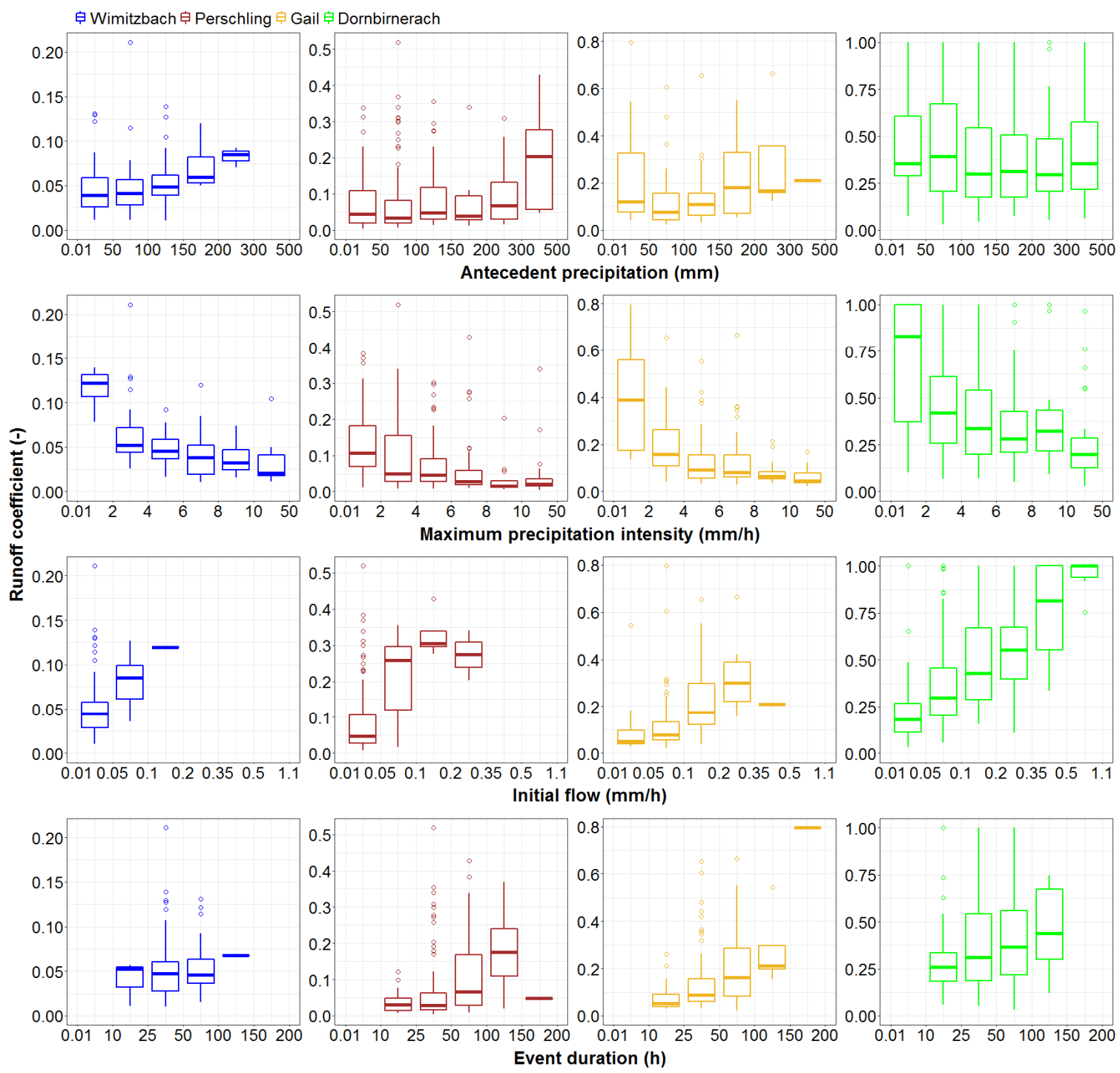

Figure 6. Variability of runoff coefficient (Rc) for different classes of antecedent precipitation, maximum precipitation intensity, initial flow prior to the event, and event duration in four selected catchments: Dornbirnerach, Gail, Wimitzbach, and Perschling. The changes are evaluated for events with precipitation volumes less than $50 \mathrm{~mm}$.

Runoff peaks are somewhat related to antecedent precipitation (Figure 7). An increase of event peaks with increasing antecedent precipitation is observed mainly in catchments with lower annual precipitation (Wimitzbach, Perschling, and Gail). An increase of Qp with increasing maximum precipitation intensity is found only for the Dornbirnerach catchment, which has a large proportion of area with shallow interflow processes. Similarly, as for Rc, Qp rises in all catchments with the increasing initial flow and is not related to the duration of a runoff event.

The variability of the recession time constant is presented in Figure 8. Tc is not related to antecedent precipitation, but it decreases with increasing precipitation intensity. An exception is Wimitzbach, which has a large proportion of deep interflow processes. In Wimitzbach, the Tc is not heavily related to the change of maximum precipitation intensity. The initial flow is not associated with the variability of Tc in most of the catchments. Only in Karstic (Gail) catchment, Tc tends to increase with the increasing initial flow before the event. The most apparent pattern is found for the event duration, where for increasing event duration also Tc tends to increase. 


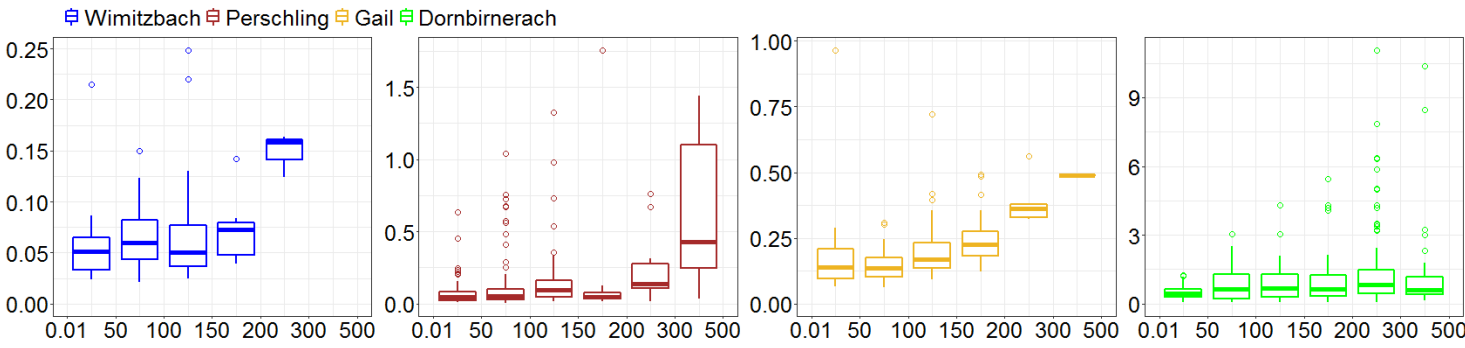
Antecedent precipitation $(\mathrm{mm})$
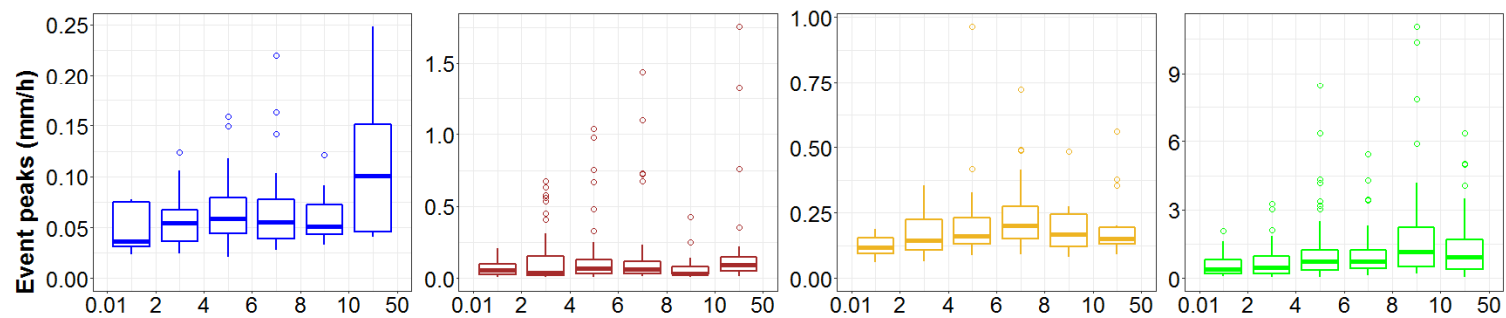

Maximum precipitation intensity $(\mathrm{mm} / \mathrm{h})$
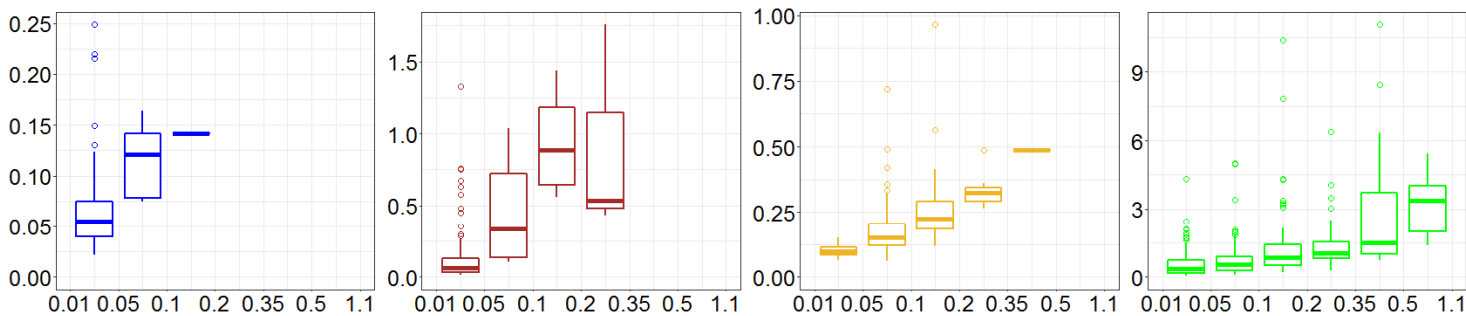

Initial flow $(\mathrm{mm} / \mathrm{h})$
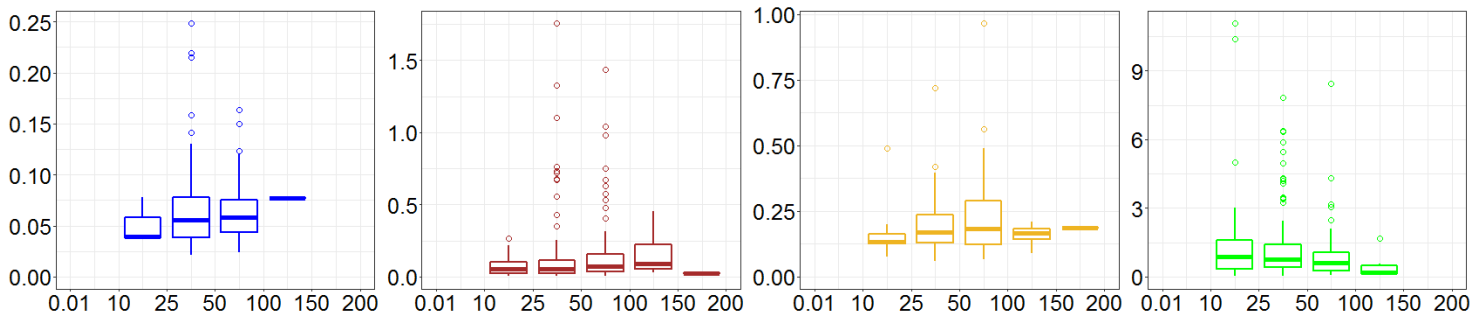

Event duration (h)

Figure 7. Variability of event peaks (Qp) for different classes of antecedent precipitation, maximum precipitation intensity, initial flow prior to the event, and event duration in four selected catchments: Dornbirnerach, Gail, Wimitzbach, and Perschling. The changes are evaluated for events with precipitation volumes less than $50 \mathrm{~mm}$.

The analysis of events, caused by precipitation volumes less than $50 \mathrm{~mm}$ (Figures 6-8), has shown that the duration of runoff events can have a noticeable effect on the variability of event runoff characteristics. The variability of Rc, Qp, and Tc for short, medium, long, and snowmelt events is presented in Figure 9 and summarized in Table 4. The results show that the largest Rc are, in all catchments, attributed to runoff events impacted by snowmelt. While Tc of melt events are generally at the same high level as long-duration events. Interestingly, antecedent precipitation for melt events is the smallest (except for Gail, where it is slightly higher than rainfall events, Table 4). In general, Rc and Tc tend to increase with the increasing duration of events. An exception is Wimitzbach, where the difference in Rc between short and long events is minimal. The patterns found for Rc and Tc are, however, not observed for runoff peaks Qp. In Dornbirnerach and Wimitzbach, Qp has the same variability for all event types. In Gail and Perschling, Qp tends to be the largest for snowmelt peaks. 

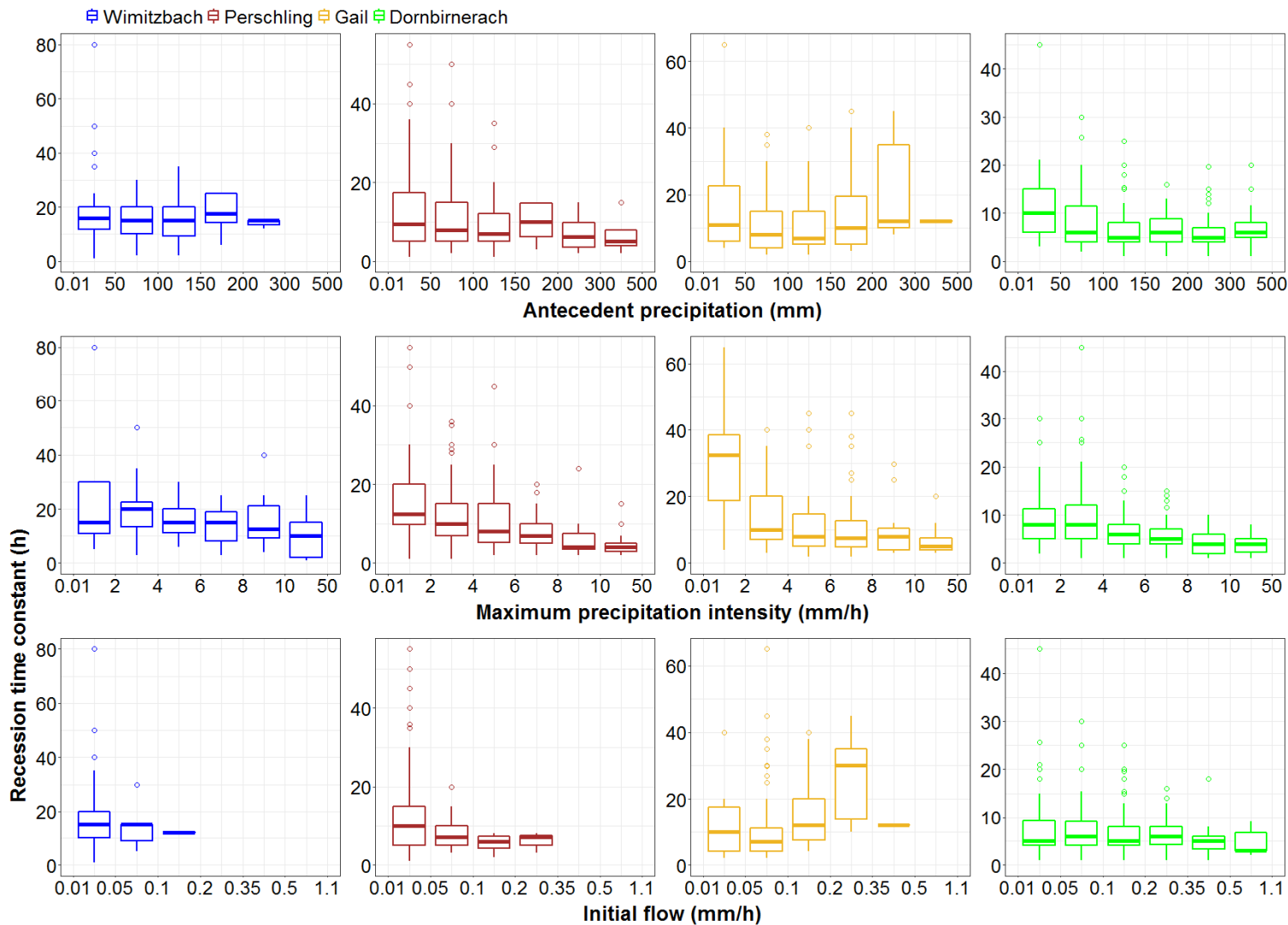
nitial flow $(\mathrm{mm} / \mathrm{h})$
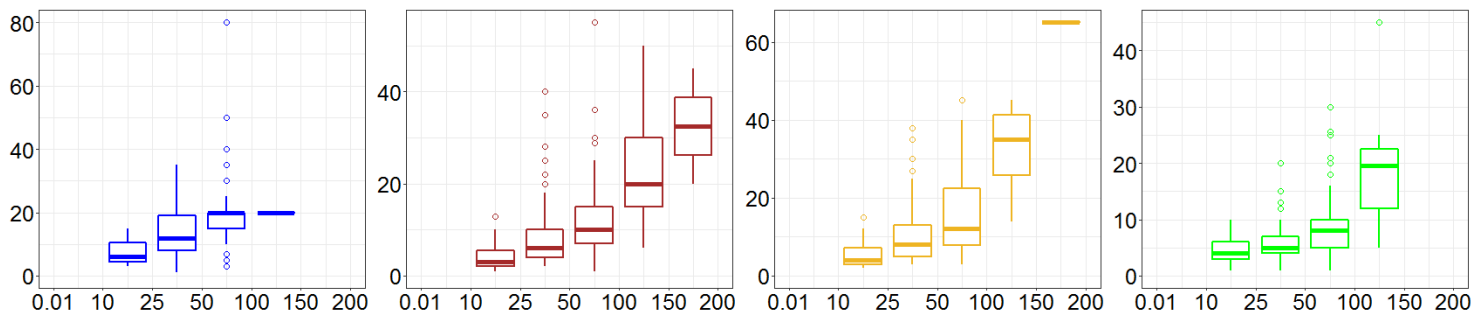

Event duration (h)

Figure 8. Variability of recession time constant (Tc) for different classes of antecedent precipitation, maximum precipitation intensity, initial flow prior to the event, and event duration in four selected catchments: Dornbirnerach, Gail, Wimitzbach, and Perschling. The changes are evaluated for events with precipitation volumes less than $50 \mathrm{~mm}$. 


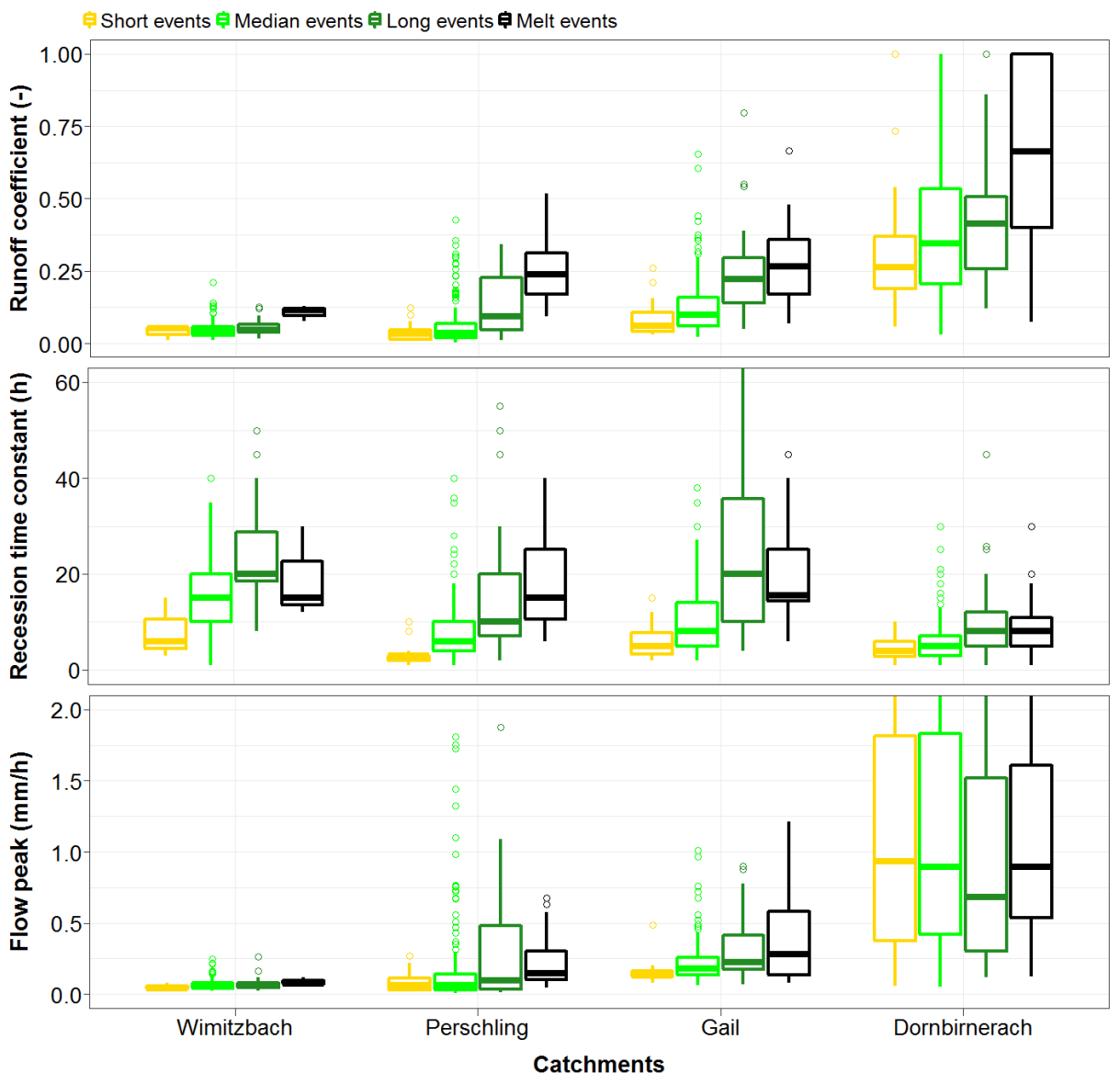

Figure 9. Variability of runoff coefficient, recession time constant, and event peaks for four types of runoff events. The type of runoff event is defined by its duration, i.e., short (duration less than $24 \mathrm{~h}$ ), medium (duration between 24 and 72 h), long (duration more than 72 h). Events with the contribution of snowmelt are classified as melt events.

Table 4. Summary of event and median values of their characteristics (median values) grouped according to four event types: short (duration less than $24 \mathrm{~h}$ ), medium (duration between 24 and $72 \mathrm{~h}$ ), long (duration more than $72 \mathrm{~h}$ ), and snowmelt (having a contribution from snowmelt).

\begin{tabular}{|c|c|c|c|c|c|c|c|}
\hline Catchments & Event Type & $\begin{array}{l}\text { No. of } \\
\text { Events }\end{array}$ & $\begin{array}{l}\text { Event Prec. } \\
(\mathrm{mm})\end{array}$ & $\begin{array}{c}\text { Max. Prec. } \\
\text { Intensity }(\mathrm{mm} / \mathrm{h})\end{array}$ & $\begin{array}{l}\text { Antec. Precip } \\
(\mathrm{mm})\end{array}$ & $\begin{array}{l}\text { Initial Flow } \\
(\mathrm{mm} / \mathrm{h})\end{array}$ & $\begin{array}{l}\text { Duration } \\
\text { (h) }\end{array}$ \\
\hline \multirow{4}{*}{ Wimitzbach } & Short & 3 & 8.3 & 6.2 & 167.5 & 0.03 & 22 \\
\hline & Medium & 87 & 22.4 & 5.2 & 86.0 & 0.03 & 46 \\
\hline & Long & 30 & 40.2 & 5.8 & 70.1 & 0.03 & 86 \\
\hline & Melt & 3 & 18.5 & 3.7 & 53.3 & 0.05 & 46 \\
\hline \multirow{4}{*}{ Perschling } & Short & 14 & 7.8 & 4.9 & 68.1 & 0.02 & 21 \\
\hline & Medium & 165 & 17.2 & 5.6 & 79.7 & 0.01 & 43 \\
\hline & Long & 49 & 29.2 & 4.4 & 65.2 & 0.02 & 84 \\
\hline & Melt & 22 & 22.6 & 2.5 & 50.0 & 0.03 & 82 \\
\hline \multirow{4}{*}{ Gail } & Short & 18 & 11.3 & 5.3 & 101.5 & 0.08 & 20 \\
\hline & Medium & 133 & 19.6 & 5.8 & 111.2 & 0.08 & 38 \\
\hline & Long & 24 & 37.4 & 5.3 & 109.0 & 0.09 & 94 \\
\hline & Melt & 16 & 27.2 & 5.6 & 118.9 & 0.17 & 75 \\
\hline \multirow{4}{*}{ Dornbirnerach } & Short & 24 & 21.9 & 8.7 & 202.3 & 0.10 & 21 \\
\hline & Medium & 294 & 28.0 & 5.7 & 198.4 & 0.08 & 46 \\
\hline & Long & 45 & 43.9 & 5.4 & 190.9 & 0.08 & 89 \\
\hline & Melt & 55 & 25.6 & 3.6 & 111.0 & 0.17 & 60 \\
\hline
\end{tabular}




\section{Discussion and Conclusions}

This study aims to examine the role of climate (i.e., event precipitation volume, precipitation intensity, and antecedent precipitation) and runoff regime (i.e., initial flow before runoff event, and event duration) on the seasonal dynamics of event runoff coefficient, recession time constant, and event peak flow in different geological settings represented by four small catchments in Austria. Previous studies have shown that at the regional scale, the event runoff coefficients are highly correlated with mean annual precipitation, but less related to soil type and land use [1,17]. Merz et al. reported that regional differences in runoff coefficient tend to be larger than the variability of runoff coefficient with event rainfall or antecedent precipitation in individual catchments [1]. The results of this study showed a similar pattern of significantly larger event runoff coefficients in the catchments with high mean annual precipitation (Dornbirnerach) than in drier catchments (Wimitzbach, Perschling). In contrast to some previous studies $[1,38]$, however, the results of this study show only poor relation between antecedent precipitation as an index of catchment wetness and event runoff response. We performed a sensitivity analysis (not shown in the results) of testing the different lengths of periods used for the estimation of antecedent precipitation with very similar results. Still, this finding is in agreement with Longobardi et al., who reported that antecedent precipitation was a generally lower predictor of catchment state than soil moisture or base flow estimates [39]. Scherrer et al. reported that the sensitivity of runoff response on antecedent wetness was related to dominant runoff generation processes, and the sensitivity was small in catchments with the dominant overland flow, but significantly larger in catchments with subsurface flow generation [7]. The role of initial flow condition and baseflow has been highlighted by Rodríguez-Blanco et al. [38]. They showed that baseflow variability appeared to be more influential than rainfall amount in controlling the hydrological response of humid catchments. We found that initial flow was the main factor influencing the magnitude of runoff coefficient and event peaks in all analyzed catchments and geological settings. The recession time constant tended to be inversely related to the maximum event precipitation intensity, with an exception for one catchment (Wimitzbach) with the largest proportion of deep interflow contribution to runoff.

The role of geology on runoff response at the event time scale was evaluated only in a few studies. Norbiato et al. analyzed the geological maps for selected catchments in the Italian Alps and derived for each catchment a permeability index [17]. They found that the 'permeability index' was an essential control of variability of runoff coefficients, particularly for catchments with mean annual precipitation less than $1200 \mathrm{~mm}$. The results of Norbiato et al. showed that the permeability was closely linked with a subsurface water storage capacity index $[17,40]$. This index related $90 \%$ daily runoff quantile to the median daily flow (Q90/Q50), and lower values corresponded to lower variance of daily flows, caused by the damping effects of groundwater storages (for example, in extensive karstified or limestone aquifers). We used in this study classification of geological features based on field mapping and hydro-geologic runoff process characterization. Based on this information, different hydro-geologic response units were defined, and the catchment proportion of areas dominated by interflow, deep groundwater flow, or surface runoff processes were estimated. We found that the largest runoff coefficients, event peaks, and fastest recession were observed in the Dornbirnerach catchment. Dornbirnerach is a catchment with very steep hillslopes, and shallow interflow processes characterize large parts of the catchment. Moreover, this catchment is very humid with large and frequent precipitation. The subsurface water storage index of Norbiato et al. was 0.28 [17], which indicated a catchment with low permeability. Low permeability index (0.39) was also found for the Perschling catchment, which is located in the Flysch zone and has almost the whole catchment in the weathering zone characterized by shallow interflow. This catchment, however, is located in lowlands, has much smaller precipitation, and rainfall is dominated in the summertime [27]. The recession time constant is short, similarly to Dornbirnerach, but the runoff coefficients are much smaller, due to much smaller rainfall. The largest proportion of deep groundwater flow was mapped in the Wimitzbach catchment. Wimitzbach is a catchment with the lowest runoff coefficients and event peaks, and largest recession time constants. It also has the highest permeability index (0.59) of Norbiato et al. [17]. Comparing the results of Perschling and 
Wimitzbach with those of Merz et al. [1], they had less than half of the median value of runoff coefficient compared to catchments with the same precipitation. The hydro-geological mapping here allowed us to explain and attribute the characteristics of runoff response, which was not possible before. The Gail catchment represents a mixture of different runoff processes. It has only a somewhat lower proportion of surface flow area than Dornbirnerach, but also a large proportion of karst (51\%). In combination with mean annual rainfall exceeding $1000 \mathrm{~mm}$, in this catchment, we observed the second-largest runoff coefficients, as well as recession time constants.

The analysis of the runoff response by different event types indicated that runoff coefficients and recession time constants increased with event snowmelt. The flood peaks tended to be larger for snowmelt events, except for one catchment (Dornbirnerach), which is very wet in all seasons. This finding is in agreement with Merz et al. [1]. They found that in a humid climate and at the scale of the small and medium catchments, the main controls of event runoff coefficients were the climate and the runoff regime through the seasonal catchment water balance, and hence, antecedent soil moisture. The runoff coefficients tended to increase in a similar order as in our study, i.e., the smallest for short rain floods, and larger for long rain floods, and snowmelt events.

Overall, this study complements our understanding of the variability of event runoff response characteristics between small catchment and regional scales. While at the small catchment scale, the runoff response is related mainly to the main runoff generation mechanism [5], at the regional scale, it is strongly correlated to climate and mean annual precipitation. Chen et al. demonstrated that in small agricultural catchments, groundwater levels explain the variability of runoff response more than soil moisture or precipitation, suggesting the role of connectivity and flow paths [5]. The use of field mapping of hydro-geological flow paths used in this study has shown the importance and usefulness of such information for interpreting the spatial and temporal variability of event runoff characteristics. This study provides an illustrative example of the link between geology, climate, and runoff response. It demonstrates the value of field hydro-geological mapping for understanding the runoff response at the medium catchment scale, which provides a basis toward improving the prediction of event runoff characteristics and to transfer the understanding to the regional scale. This is particularly important for improving the understanding and prediction of runoff response in changing climate conditions. Increasing or decreasing precipitation and the possible shifts in climate zones will have a significant impact on runoff generation, and hence, runoff response and water availability at the small catchment and regional scales.

Supplementary Materials: The following are available online at http://www.mdpi.com/2073-4441/12/12/3457/s1, Table S1: List of events with runoff coefficient Rc, recession time constant $T c(h)$ and peak discharge Qp $(\mathrm{mm} / \mathrm{h})$.

Author Contributions: Conceptualization, J.P. and G.B.; methodology, X.C.; software, X.C.; validation, B.S. and X.C.; formal analysis, X.C.; investigation, J.P.; resources, J.P. and A.V.; data curation, X.C.; writing—original draft preparation, X.C.; writing-review and editing, J.P., B.S., P.V., A.V., G.B. and X.C.; visualization, J.P. and X.C.; supervision, G.B.; project administration, G.B.; funding acquisition, G.B. All authors have read and agreed to the published version of the manuscript.

Funding: This research was funded by Austrian Science Funds (FWF) as part of the Vienna Doctoral Program on Water Resource Systems, grant number DK W1219-N28 and the China Scholarship Council (CSC). Open Access Funding by the Austrian Science Fund (FWF).

Acknowledgments: The authors would like to acknowledge financial support provided by the Austrian Science Funds (FWF) as part of the Vienna Doctoral Program on Water Resource Systems (DK W1219-N28) and the China Scholarship Council (CSC).

Conflicts of Interest: The authors declare no conflict of interest.

\section{References}

1. Merz, R.; Blöschl, G.; Parajka, J. Spatio-temporal variability of event runoff coefficients. J. Hydrol. 2006, 331, 591-604. [CrossRef]

2. Czikowsky, M.J.; Fitzjarrald, D.R. Evidence of Seasonal Changes in Evapotranspiration in Eastern U.S. Hydrological Records. J. Hydrometeorol. 2004, 5, 974-988. [CrossRef] 
3. García-Ruiz, J.M.; Regüés, D.; Alvera, B.; Lana-Renault, N.; Serrano-Muela, P.; Nadal-Romero, E.; Navas, A.; Latron, J.; Martí-Bono, C.; Arnáez, J. Flood generation and sediment transport in experimental catchments affected by land use changes in the central Pyrenees. J. Hydrol. 2008, 356, 245-260. [CrossRef]

4. Viglione, A.; Rogger, M.; Pirkl, H.; Parajka, J.; Blöschl, G. Conceptual model building inspired by field-mapped runoff generation mechanisms. J. Hydrol. Hydromech. 2018, 66, 303-315. [CrossRef]

5. Chen, X.; Parajka, J.; Széles, B.; Strauss, P.; Blöschl, G. Spatial and temporal variability of event runoff characteristics in a small agricultural catchment. Hydrol. Sci. J. 2020, 65, 2185-2195. [CrossRef]

6. Chen, X.; Parajka, J.; Széles, B.; Strauss, P.; Blöschl, G. Controls on event runoff coefficients and recession coefficients for different runoff generation mechanisms identified by three regression methods. J. Hydrol. Hydromech. 2020, 68, 155-169. [CrossRef]

7. Scherrer, S.; Naef, F.; Faeh, A.O.; Cordery, I. Formation of runoff at the hillslope scale during intense precipitation. Hydrol. Earth Syst. Sci. Discuss. 2007, 11, 907-922. [CrossRef]

8. Ruggenthaler, R.; Schöberl, F.; Markart, G.; Klebinder, K.; Hammerle, A.; Leitinger, G. Quantification of Soil Moisture Effects on Runoff Formation at the Hillslope Scale. J. Irrig. Drain. Eng. 2015, 141, 05015001. [CrossRef]

9. Liu, J.; Engel, B.A.; Wang, Y.; Wu, Y.; Zhang, Z.; Zhang, M. Runoff Response to Soil Moisture and Micro-topographic Structure on the Plot Scale. Sci. Rep. 2019, 9, 2532. [CrossRef]

10. Joel, A.; Messing, I.; Seguel, O.; Casanova, M. Measurement of surface water runoff from plots of two different sizes. Hydrol. Process. 2002, 16, 1467-1478. [CrossRef]

11. Cerdan, O.; Le Bissonnais, Y.; Govers, G.; Lecomte, V.; van Oost, K.; Couturier, A.; King, C.; Dubreuil, N. Scale effect on runoff from experimental plots to catchments in agricultural areas in Normandy. J. Hydrol. 2004, 299, 4-14. [CrossRef]

12. Burns, D.; Vitvar, T.; McDonnell, J.; Hassett, J.; Duncan, J.; Kendall, C. Effects of suburban development on runoff generation in the Croton River basin, New York, USA. J. Hydrol. 2005, 311, 266-281. [CrossRef]

13. Western, A.W.; Blöschl, G.; Grayson, R.B. How well do indicator variograms capture the spatial connectivity of soil moisture? Hydrol. Process. 1998, 12, 1851-1868. [CrossRef]

14. James, A.L.; Roulet, N.T. Investigating hydrologic connectivity and its association with threshold change in runoff response in a temperate forested watershed. Hydrol. Process. 2007, 21, 3391-3408. [CrossRef]

15. Silasari, R.; Parajka, J.; Ressl, C.; Strauss, P.; Blöschl, G. Potential of time-lapse photography for identifying saturation area dynamics on agricultural hillslopes. Hydrol. Process. 2017, 31, 3610-3627. [CrossRef]

16. Gottschalk, L.; Weingartner, R. Distribution of peak flow derived from a distribution of rainfall volume and runoff coefficient, and a unit hydrograph. J. Hydrol. 1998, 208, 148-162. [CrossRef]

17. Norbiato, D.; Borga, M.; Merz, R.; Blöschl, G.; Carton, A. Controls on event runoff coefficients in the eastern Italian Alps. J. Hydrol. 2009, 375, 312-325. [CrossRef]

18. Penna, D.; Tromp-van Meerveld, H.; Gobbi, A.; Borga, M.; Dalla Fontana, G. The influence of soil moisture on threshold runoff generation processes in an alpine headwater catchment. Hydrol. Earth Syst. Sci. 2011, 15, 689-702. [CrossRef]

19. Brammer, D.D.; McDonnell, J.J. An evolving perceptual model of hillslope flow at the Maimai catchment. Adv. Hillslope Process. 1996, 1, 35-60.

20. Onda, Y.; Komatsu, Y.; Tsujimura, M.; Fujihara, J.-I. The role of subsurface runoff through bedrock on storm flow generation. Hydrol. Process. 2001, 15, 1693-1706. [CrossRef]

21. Vannier, O.; Anquetin, S.; Braud, I. Investigating the role of geology in the hydrological response of Mediterranean catchments prone to flash-floods: Regional modelling study and process understanding. J. Hydrol. 2016, 541, 158-172. [CrossRef]

22. Tague, C.; Grant, G.E. A geological framework for interpreting the low-flow regimes of Cascade streams, Willamette River Basin, Oregon. Water Resour. Res. 2004, 40, W04303. [CrossRef]

23. Weiler, M.; McDonnell, J.J. Conceptualizing lateral preferential flow and flow networks and simulating the effects on gauged and ungauged hillslopes. Water Resour. Res. 2007, 43, W03403. [CrossRef]

24. Krakauer, N.Y.; Temimi, M. Stream recession curves and storage variability in small watersheds. Hydrol. Earth Syst. Sci. 2011, 15, 2377-2389. [CrossRef]

25. Dung, B.X.; Gomi, T.; Miyata, S.; Sidle, R.C. Peak flow responses and recession flow characteristics after thinning of Japanese cypress forest in a headwater catchment. Hydrol. Res. Lett. 2012, 6, 35-40. [CrossRef] 
26. Rinaldo, A.; Beven, K.J.; Bertuzzo, E.; Nicotina, L.; Davies, J.; Fiori, A.; Russo, D.; Botter, G. Catchment travel time distributions and water flow in soils. Water Resour. Res. 2011, 47, W07537. [CrossRef]

27. Gaál, L.; Szolgay, J.; Kohnová, S.; Parajka, J.; Merz, R.; Viglione, A.; Blöschl, G. Flood timescales: Understanding the interplay of climate and catchment processes through comparative hydrology. Water Resour. Res. 2012, 48, W04511. [CrossRef]

28. Tetzlaff, D.; Soulsby, C.; Waldron, S.; Malcolm, I.A.; Bacon, P.J.; Dunn, S.M.; Lilly, A.; Youngson, A.F. Conceptualization of runoff processes using a geographical information system and tracers in a nested mesoscale catchment. Hydrol. Process. 2007, 21, 1289-1307. [CrossRef]

29. Rogger, M.; Pirkl, H.; Viglione, A.; Komma, J.; Kohl, B.; Kirnbauer, R.; Merz, R.; Blöschl, G. Step changes in the flood frequency curve: Process controls. Water Resour. Res. 2012, 48, W05544. [CrossRef]

30. Pirkl, H. Hydrogeologische und Geohydrologische Grundlagen für die Ausgewählten Leiteinzugsgebiete—Unveröffentl. Bericht im Rahmen Projekt Hochwasser Tirol (HOWATI); Geologische Bundesanstalt: Vienna, Austria, 2009.

31. Pirkl, H. Untergrundabhängige Abflussprozesse. In Kartierung und Quantifizierung für das Bundesland Tirol; Flächendeckende Aufnahme Osttirols; Geologische Bundesanstalt: Vienna, Austria, 2012.

32. Rogger, M.; Kohl, B.; Pirkl, H.; Viglione, A.; Komma, J.; Kirnbauer, R.; Merz, R.; Blöschl, G. Runoff models and flood frequency statistics for design flood estimation in Austria-Do they tell a consistent story? J. Hydrol. 2012, 456-457, 30-43. [CrossRef]

33. Chapman, T.; Maxwell, A. Baseflow separation-comparison of numerical methods with tracer experiments. In Proceedings of the Hydrology and Water Resources Symposium 1996: Water and the Environment; Preprints of Papers; Institution of Engineers: Barton, Australia, 1996; p. 539.

34. Duan, Q.; Sorooshian, S.; Gupta, V. Effective and efficient global optimization for conceptual rainfall-runoff models. Water Resour. Res. 1992, 28, 1015-1031. [CrossRef]

35. Viglione, A.; Parajka, J. TUWmodel: Lumped/Semi-Distributed Hydrological Model for Education Purposes; R Package Version 1.1-1. Available online: https://cran.r-project.org/web/packages/TUWmodel/index.html (accessed on 26 February 2020).

36. Parajka, J.; Merz, R.; Blöschl, G. Uncertainty and multiple objective calibration in regional water balance modelling: case study in 320 Austrian catchments. Hydrol. Process. 2007, 21, 435-446. [CrossRef]

37. Patnaik, S.; Biswal, B.; Nagesh Kumar, D.; Sivakumar, B. Effect of catchment characteristics on the relationship between past discharge and the power law recession coefficient. J. Hydrol. 2015, 528, 321-328. [CrossRef]

38. Rodríguez-Blanco, M.L.; Taboada-Castro, M.M.; Taboada-Castro, M.T. Rainfall-runoff response and event-based runoff coefficients in a humid area (northwest Spain). Hydrol. Sci. J. 2012, 57, 445-459. [CrossRef]

39. Longobardi, A.; Villani, P.; Grayson, R.; Western, A. On the relationship between runoff coefficient and catchment initial conditions. In Proceedings of the MODSIM, Townsville, Canberra, Australia, 14-17 July 2003; pp. 867-872.

40. Borga, M.; Boscolo, P.; Zanon, F.; Sangati, M. Hydrometeorological Analysis of the 29 August 2003 Flash Flood in the Eastern Italian Alps. J. Hydrometeorol. 2007, 8, 1049-1067. [CrossRef]

Publisher's Note: MDPI stays neutral with regard to jurisdictional claims in published maps and institutional affiliations.

(C) 2020 by the authors. Licensee MDPI, Basel, Switzerland. This article is an open access article distributed under the terms and conditions of the Creative Commons Attribution (CC BY) license (http://creativecommons.org/licenses/by/4.0/). 